\title{
Construction of A Learning Society and Sports Culture of College Campus
}

\author{
Xiaohui Che \\ Sport Department of Jiangsu University \\ Zhenjiang, China 212013
}

\begin{abstract}
A learning society is a kind of ideal social form, which is designed for the education development and learning activities in future by the lifelong education advocates. This paper discussed some problems related to the construction of a learning society and sports culture of college campuses based on the historical inevitability to construct a learning society as well as the basic meaning, operation mechanism and culture characteristics of the learning society. Moreover, this study can provide a certain reference for the physical education of colleges and curriculum reform in China.
\end{abstract}

\section{Keywords—learning society; campus; sports culture}

\section{INTRODUCTION}

Lifelong education is a kind of educational ideological trend to affect the world. However, a learning society is a revolution to change the educational history. They are both the revolutionary events in the contemporary educational history. The learning society is a kind of new concept of society development proposed from a perspective of lifelong education. With the propagation and practice of lifelong education ideological trend and the learning society management concept, the formation of a learning society is one of the important symbol to build a well-off society in an all-round way in China. It has an important reference significance for the higher physical education reform and campus sports culture construction to understand the basic meaning and operation mechanism of the learning society.

\section{BASIC MEANING OF LEARNING SOCIETY}

Robert maynard hutchins, as an outstanding educator and a representative of perpetualism education school, has pointed out that the learning society not only would provide abundant education opportunities to help all the members of society, including the adults, constantly learn in their lives but also was a kind of educational spirit and educational faith to make the learner continue to grow and develop. Nowadays, China are facing many problems during the economic transformation period, such as population increase, aging of population, more leisure time, and so on, and the key to solve these problems is to earnestly implement the "strategy of reinvigorating the country through science and education" and the strategy of "sustainable development", to vigorously advocate lifelong education and learning from improving the comprehensive quality of citizens, as well as to build a learning society based on the modern education means, school education and community education.

\section{SIX MAJOR CULTURAL CHARACTERISTICS OF LEARNING SOCIETY FROM A PERSPECTIVE OF SOCIAL CULTURE}

United Nations Educational, Scientific, and Cultural Organization has emphasized that the learning society was a kind of ideal social form which was designed for the education development and learning activities in future by the lifelong education advocates. The learning society has six major cultural characteristics from a perspective of social culture.

- Learning ability culture: the learning ability is the source of vitality and competitiveness of learning society. In the learning society, the ability is more important than learning, and the learning ability is more important than ability. The learning ability includes three major elements of motivation, perseverance, and ability, as well as the learning ability fundamentally supports advance with the times and rapid development of the whole society.

- Happy life culture: the learning society can provide a environment to live and work in peace and contentment for the social members and can make the social members realize the lives meaning. These are also the fundamental purpose and starting point to construct the learning society. Moreover, the lifelong sports contain broad happy sports thought, which coincides with the characteristics of happy life culture in the learning society.

- Innovation culture: the learning society enables the social members to continue to create themselves and future energy. "Continuous creation" is the core content of the learning organization, and innovation is the soul of a nation progress. Hence, the innovation culture is the core to build the learning society.

- Reflection culture: the social members are good at reflection in a learning society. The learning organization theory strongly emphasized reflection and thought that the reflection was the most learning and the basis of learning. In a learning society, the individual should has the reflection habit, the family should has the reflection activities, the community should has the reflection atmosphere, and the society should has the reflection culture. 
- Sharing culture: a learning society must be able to make all social members fully share the learning resources. In an information era, the learning society should make full use of network information technology, construct the shared learning system for the social members, and build the cultural atmosphere of resource sharing.

- Speed culture: the learning society pursues the speed and efficiency, and the competitions among enterprises, cities and countries, respectively, are fundamentally the competition in the learning speed in the world today. Speed is a kind of advanced social culture and spirit to construct learning society, which should be greatly carried forward.

\section{SPORTS CUlture AND ItS FunCtion OF COLLEGE CAMPUSES}

As a part of the culture, the physical education plays a special role in the development and progress of human civilization. The sports culture of campuses is one of the main contents of campus culture and has bright colors of modern sports culture and the modern sports education. Therefore, the sports culture of campuses is a kind of existence and development form in the specific college campus environment. College sports spirit is the soul of college sports culture as well as the core content of sports culture construction in colleges and plays an important role in the teaching, management and spiritual civilization construction of colleges. Furthermore, the college sports spirit is an important path to carry forward the Chinese sports spirit and national spirit. So we should advocate the correct sports culture as well as cultivate scientific and positive college sports spirit culture with era characteristics. College sports culture, as a convergence system of campus culture and sports culture, not only gathers the main functions of campus culture and sports culture but also plays its unique effect in the specific college campuses environment, such as education function, guiding function, standard constraint function, individuality shaping function, ability formation function, mentality adjustment function, fitness function, cohesion function, creation function, radiation function and entertainment function, window function, and etc.

\section{CONSTRUCTION OF CAMPUS SPORTS CULTURE IN LEARNING SOCIETY}

\section{A. Attaching Great Importance to Strategic Transfer of College Sports Curriculum Properties}

The basic property of traditional and existing college sports curriculum was the "physical education", moreover, the main purpose of "physical education" was to enhance students' constitution. However, the future college sports curriculum property should be the generalized cultural education curriculum. The concept in the cultural education curriculum is a great culture concept from a cultural significance. It is not limited to the culture of knowledge form but is a kind of culture as a thinking way and even production mode, including spiritual form, institutional form and material form. The "cultural education" not only need impart some knowledge, cultivate the necessary skills, enhance the students' physique and form good habits but also should make the sports gradually formed and consolidated as a kind of thinking way, behavior way and life style in the process of college sports work. This strategic transfer of sports curriculum property is a directional problem of Chinese college sports reform and development. It brings an inevitable challenge to Chinese college sports as well as makes a revolutionary reform for the education ideas, work manner and assessment standard of traditional and existing college sports.

\section{B. Improvement of Cultural Grade and Sports Accomplishment of Students and Abundance of Sports Culture Knowledge of Students}

In a learning society, as the cultural education class, the contents of sports classes should be more abundant, as well as the form should be more lively and more intriguing. No matter in which level of colleges the "great cultural sports curriculum" is, the colleges should increase more interests, improve the cultural grade of students, sports accomplishment and humanistic knowledge of sports. Sports knowledge is not only the technical knowledge but also has many constituents belonging to humanistic and social science. This has been verified by the fact that China has taken the sports as a first-level discipline of social sciences. Therefore, it is necessary to provide the sports humanities knowledge for the students as much as possible in order to improve the sports accomplishment of students. The core goal of higher education is to cultivate qualified talents for the society. In the future learning society, the talents mode needed by our society would be greatly changed, moreover, the greatest change is that the talents should have stronger self-study ability. In addition, the learning society should cultivate the "Will learn" talents, namely, the college sports teaching would transform from "Learn to teaching" to "Will learn teaching".

\section{Establishment of "Lifelong Sports" and "People- oriented" Education Concept and Prominence of "New, Refined, Practical" Characteristics of Teaching Contents}

Many studies have shown that the "lifelong sports" thought was the dominant thought to adapt the college sports teaching in our country in the current and future learning society. Its advantages lied in emphasizing the pursuit of goals, such as ability, habit, interest, consciousness of the sports, which were ignored by the thoughts of "physique enhancement" and "technical education". In addition, in order to meet the talent needs of the learning society, the colleges sports teaching must establish a "people-oriented" education concept and take the all-round development of students as the starting point and end result. Furthermore, the college sports teaching should promote all-round development of students individuality, promote various potentials to be given full play to, promote the personality fulness of students, and promote the moral, intellectual and physical improvement of students, so as to cultivate the developable students. Hence, this is a new development concept with the "continuous" and "coordinating" development as the purpose. In order to meet the talent needs 
of the learning society, the sports teaching content should give prominence to the "new, refined, practical" characteristics. More importantly, the sports culture education should be added into the teaching contents, especially, the sports spirit culture education should be strengthened. The valuable thought, style and consciousness with the enlightenment and influence effects, which were contained in the sports, were permeated to the students by teaching, so as to promote the individuality development of students and form sound personality.

\section{Prominence of Behavioral Norms Functions of the Campus Sports Culture and Shaping of Modern Strong Personality of Students}

For contemporary college students, the cultural environment with a convergence of various social ideological trend not only created the opportunities to draw abundant nourishment for them but also brought challenges to their identification ability and innovation ability. First of all, the college students need the help in time, and the guidance should be given to them by the use of the guiding function of campus culture, so as to ensure that they can choose the cultural concept according with socialist development requirements in the complex social ideological trend as well as to make the campus sports culture construction correctly develop along the orbit of socialist culture.

Secondly, we should guide the students to objectively analyze various social ideological trends, correctly advocate positive campus culture, highlight the theme of campus culture, carry out the elegant and healthy campus sports culture activities, highlight the behavioral norms functions of the campus sports culture, and correctly map the advancement and characteristic of times of social ideological trend.

Thirdly, we should strengthen the innovation of the social culture and build a spiritual home to make the social members feel ideal and significative. The campus sports culture construction not only has the significance to provide the spiritual pillar and value orientation but also has the effect on the psychological comfort and behavioral adjustment as well as even the functions to express emotion and release pressure. A campus sports culture system full of vigor and vitality would show bright guiding role and strong integrated capability.

Finally, we should vigorously carry forward the unyielding spirit of Chinese nation and combine the "swifter, higher and stronger" Olympic spirit to shape the modern strong personality of the contemporary college students. The unyielding spirit is an extremely valuable part of our national spirit. Moreover, if the unyielding spirit combines with the modern rational spirit, self-supporting consciousness and Olympic spirit, a newer and more comprehensive strong personality would be shaped, which is a kind of mental trait needed by modern society.

\section{REFERENCES}

[1] Zhang Shengxiong and Xu Yunfa. Construction of a learning society with Chinese characteristics[M]. Jiangxi People Press, 2003. 01.

[2] Hao Qin. Olympic spirit and Chinese traditional culture [J]. Literature and history of physical education, 2001. 02.

[3] Han Min, Li Pengcheng. Contemporary cultural philosophy thought [J]. People's Education Press, 1994.

[4] Huang Junwei. Discussion on rational sports culture concept of sports teachers [J]. Journal of Nanjing Sport Institute. 2003. 01.

[5] Wang Yuechuang. Postmodernism and Chinese contemporary culture [J]. Social Sciences in China, 1996.03.

[6] XiongLei. Discussion on life-long education and learning society [J]. Journal of Yang Zhou University (higher education research version), 1998. 02 